\title{
Dziedzictwo jako scena rytualna. Przypadek Starego Miasta w Krakowie
}

\section{Abstract \\ Heritage as a Ritual Scene. The Case of the Old Town in Kraków}

In 1978 the Old Town in Kraków was listed as a World Heritage Site by the UNESCO, while during 1994 the Polish government officially pronounced it a "national historic monument". Nowadays, the space of the Old Town serves not only as one of the major Polish tourist attractions, but also reveals complex symbolic dimensions used by contemporary Poles in their current debates about national identity, political stance, relation to the past etc.

The author analyses the Old Town in Kraków as a palimpsest comprising of signs of the past imprinted in historical architecture, churches and monuments. The past of the city is being re-read and reinterpreted in diverse (both recurring and incidental) political, religious and cultural rituals. The history of the city and its spaces defined as "heritage" are being used by different groups and refer to different political and religious worldviews. The paper focuses on two political events that took place within the Old Town scape in October 2016, namely: the Black Protest (females protesting against tightening of abortion law in Poland) and the White March (pro-life and Roman Catholic Church oriented event). Juxtaposing these two public events reveals contrasting and diverse usage of the potential of the heritage embodied through the Old Town spaces in Kraków.

Keywords: anthropology, heritage, politics, religion, ritual, feminism, nationalism, urban anthropology

Przypadek Starego Miasta w Krakowie skupia jak w soczewce w zasadzie wszystkie najważniejsze paradoksy i dylematy, jakie wiążą się z posiadaniem statusu dziedzictwa. $Z$ jednej strony jest ono uznane za dobro wspólne o znaczeniu ogólnoświatowym, usankcjonowane przez UNESCO jako globalną instytucję 
certyfikującą, z drugiej zaś odgrywa rolę Narodowego Pomnika Historii, którego status potwierdził w 1994 roku swoim autorytetem prezydent RP' . Kosmopolityczny charakter Rynku Głównego z ciągnącymi się wokół ogródkami kawiarnianymi, restauracjami i pubami urządzonymi w zabytkowych piwnicach przyciąga tłumy turystów z całego świata ${ }^{2}$ i niejednokrotnie wchodzi w konflikt z lokalnym wyobrażeniem tego miejsca jako godnego szacunku narodowego dziedzictwa i „salonu miasta”, wypełnionego obiektami sakralnymi i pamiątkami zmaterializowanymi w budynkach, tablicach i pomnikach. Tętniące na co dzień beztroskim, turystyczno-rozrywkowym życiem Stare Miasto zmienia więc od czasu do czasu swoje oblicze i „wraca” ostentacyjnie do tubylców, którzy na chwilę przejmują nad nim władzę. Staje się wówczas sceną, na której rozgrywane są różne, często konkurujące ze sobą spektakle tożsamościowe, skonstruowane z rozmaitych heterogenicznych kodów kulturowych i tekstów, zapisanych w tutejszej ikonosferze. Szczegółowe prześledzenie ich przebiegu, rekonstrukcja tras marszów i podejmowanych w konkretnych miejscach praktyk rytualnych stwarzają możliwość zrekonstruowania społecznej mapy wyobraźni różnych wspólnot, które wykorzystując pozornie identyczne fragmenty centrum, uznają je za własne, wydobywają z nich odmienne warstwy znaczeń, dopasowane do własnych programów ideowych i aktualnych interesów politycznych. Wybrane punkty Starego Miasta stają się wówczas gorącymi semantycznie punktami - miejscami jawnych i ukrytych konfliktów, w których legitymacją dziedzictwa gra się mniej lub bardziej otwarcie.

Prowadzone od października 2016 roku w ramach projektu HERA ${ }^{3}$ badania nad rytualną topografią Starego Miasta pozwalają wskazać kilka strategicznych punktów, wokół których można zaobserwować postępujący od kilku lat coraz dynamiczniej proces intensyfikacji zbiorowych działań symbolicznych. Do takich gorących miejsc należy oczywiście Wawel, a ściślej katedra oraz krypta pod Wieżą Srebrnych Dzwonów, gdzie znajduje się sarkofag Lecha i Marii Kaczyńskich, Krzyż Pamięci Narodowej, zwany potocznie Krzyżem Katyńskim, zlokalizowany u wylotu ul. Grodzkiej na placu im. Ojca Adama Studzińskiego, okno papieskie w pałacu biskupim przy ul. Franciszkańskiej, a także obiekty znajdujące się na pły-

1 Stare Miasto w Krakowie zostało wpisane na listę światowego dziedzictwa UNESCO jako jeden z pierwszych obiektów już w 1978 roku. Równie szybko znalazło się także na krajowej liście Narodowych Pomników Historii. Zgodnie z przepisami Narodowego Instytutu Dziedzictwa eksperckiej agendy Ministerstwa Kultury i Dziedzictwa Narodowego - za Pomniki Historii uznaje się zabytki „kształtujące tożsamość społeczną i budujące poczucie więzi narodowej”. Więcej na ten temat na stronie internetowej Narodowego Instytutu Dziedzictwa: https://www.nid.pl/pl/Informacje_ogolne/Ochrona_dziedzictwa_kulturowego/ (dostęp: 10.11.2017).

2 W 2015 roku liczba turystów, którzy przyjechali do Krakowa, przekroczyła 10 milionów.

3 Projekt badawczy HERILIGION - The Heritagization of Religion and the Sacralization of Heritage in Contemporary Europe (Fundusz UE HORIZON 2020, grant nr 649307) jest realizowany w IEiAK UJ pod kierunkiem Anny Niedźwiedź. Opis projektu można znaleźć na stronie: http:// www.etnologia.uj.edu.pl/kadra/badania/heriligion.poland (dostęp: 10.11.2017). 
cie Rynku Głównego - pomnik Adama Mickiewicza, kościół św. Wojciecha i wieża ratuszowa. Miejsca te nie tylko znajdują się na trasie politycznych demonstracji, marszów poparcia i kontestacji, ale często wyznaczają symbolicznie ich początek i koniec, stając się wówczas sceną, na której rozgrywane są przygotowane przez organizatorów rytuały ${ }^{4}$. Ze względu na lokalizację ich odbiorcami mimowolnie są także turyści, którzy często przyglądają się z zaciekawieniem odgrywanym scenom, czasem je fotografują, traktując jako część lokalnego folkloru.

\section{Dziedzictwo a praktyki tożsamościowe}

Potocznie uznawane za oczywiste i naturalne, dziedzictwo należy obecnie do najważniejszych kategorii wyobraźni społecznej, związanych z jej wymiarem tożsamościowym. Obserwowany współcześnie potężny ruch społeczny, skupiony na odszukiwaniu, konstruowaniu i zarządzaniu tak materialnymi, jak i zupełnie pozbawionymi materialnej substancji dobrami kulturowymi, określanymi tym mianem, zdaje się o wiele skuteczniej odpowiadać na trudne pytania o przeszłość niż pamięć świadków i pozytywistycznie pojmowana historia, skoncentrowana na chłodnej i ścisłej faktografii. W perspektywie dziedzictwa to, co minione, łączy się bowiem teleologicznie nie tylko z teraźniejszością, ale zostaje również wpisane $\mathrm{w}$ wizję przyszłości, nadając sens istnienia wspólnocie, która się z nim emocjonalnie identyfikuje. Choć podyktowany jej interesami dobór miejsc, faktów, bohaterów etc. ma charakter wybiórczy, złożony z nich obraz przeszłości sprawia wrażenie spójnego i - co nie mniej ważne z punktu widzenia tak autorów, jak i potencjalnych odbiorców - atrakcyjnego dzięki zastosowaniu odpowiednich zabiegów retorycznych i konwencji literackich. Romantyczne, sensacyjne, a nawet fantastyczne wątki, które wplata się w patrymonialne narracje o przeszłości, czynią ją nie tylko bardziej atrakcyjną, ale pomagają też zneutralizować kryjące się za nimi dylematy i konflikty.

W kontekście procesów tożsamościowych traktowanie przeszłości jako patrymonium ma jednak jeszcze bardziej dalekosiężne skutki. Wyobrażeniowy charakter dziedzictwa czyni z niego skuteczne narzędzie budowania i integrowania wspólnoty, która w ten sposób tworzy obraz samej siebie. W odróżnieniu od historii, skupionej na kumulowaniu wiedzy i jej nieustannej weryfikacji, dziedzictwo opiera się przede wszystkim na postawie zawierzenia, domagając się grupowej akceptacji i lojalności. W zamian jego posiadacze otrzymują pewność trwania mimo gwałtownie zmieniającej się wokół rzeczywistości, mogą zarzucić kotwicę w „płynnej nowoczesności” i uwolnić się od wątpliwości, które rodzi skrupulatna

4 Odnoszę się tu do szerokiego rozumienia rytuału, jakie zaproponował w kontekście praktyk komunikacyjnych Eric Rothenbuhler. Rytuał stanowi według niego „[...] dobrowolne wykonanie odpowiednio uwzorowanego zachowania w celu symbolicznego oddziaływania na życie poważne lub uczestnictwa w nim" (2003: 45). 
analiza faktów i źródeł. Na związek między potrzebą zamanifestowania trwałości wspólnoty a dziedzictwem zwraca wyraźnie uwagę David Lowenthal, pisząc:

Historia opowiada, jak rzeczy stały się tym, co znamy obecnie. Dziedzictwo zaś przekazuje mity wyłącznego początku i trwania, które nas wyposażają w prestiż i determinację. Wyłączność jest konieczna, by przetrwać i by trwać jako wspólnota w dobrym stanie (1998, za Kowalski 2013: 80).

Uznanie przeszłości za swoją, objęcie jej we wspólnotowe posiadanie pociąga za sobą jednocześnie konieczność zmierzenia się także z tymi jej fragmentami, które z punktu widzenia chłodnej faktografii powinny być jej obce. Tego rodzaju nieciągłości, pęknięcia, historyczne nieścisłości patrymonialnych narracji nie budzą w posługujących się nimi wspólnotach takiego niepokoju, jak mogliby przypuszczać historiografowie, gdyż nie pojawiają się tam przypadkowo. Balansując między wykluczeniem a zawłaszczeniem, niechęcią a afirmacją, dziedzictwo pomaga wspólnocie odnaleźć sens jej istnienia. Dzięki swej ambiwalentnej, pełnej paradoksów naturze jest ono wyjątkowo elastycznym i popularnym obecnie instrumentem społecznej identyfikacji, wskazując różnym grupom społecznym miejsce w otaczającym je świecie. O tej właściwości dziedzictwa znakomicie pisze Krzysztof Kowalski:

\footnotetext{
Mityczność dziedzictwa nie wyraża się jednak w pełni w jego apokaliptycznej teleologiczności (np. obiekt konfliktu), gdyż w złowrogim kontekście nie wyczerpuje się całość jego wyraźnie dwoistego potencjału. Dziedzictwo bowiem z jednej strony usprawiedliwia zniszczenie, a z drugiej - może adoptować i uczynić „naszymi” „cudze” dobra i krzywdy. Zmiana perspektywy aksjologicznej powoduje zachowanie dóbr, które do tej pory nie budziły niczyjego zainteresowania. Daje to swoistą obietnicę waloryzowania i ochrony innych dóbr niż wyłącznie „nasze”. Dziedzictwo nosi więc w sobie zarówno zarzewie konfliktu, jak i ziarno nadziei, że możliwy jest stan, w którym „cudze” dobra oraz „cudze” ofiary, zwycięstwa i sukcesy, staną się „nasze” (Kowalski 2013: 142).
}

Dzięki zdolności łączenia antynomii dziedzictwo staje się więc cennym narzędziem uprawiania polityki i przedmiotem rywalizacji na różnych szczeblach władzy, począwszy od poziomu niewielkich społeczności lokalnych, a skończywszy na wielkich instytucjach ponadnarodowych (Harrison 2015; Neal 2015; Schramm 2015). Jak skomplikowane i delikatne to jednak narzędzie, przekonują się zwłaszcza ci twórcy tekstów kanonicznych - politycy, przedstawiciele Kościoła, pracownicy instytucji kultury, regionaliści, członkowie lokalnych stowarzyszeń, którzy próbują wprowadzić znaczące zmiany do struktury pamięci, opartej na stałych, relatywnie niezmiennych w czasie tzw. figurach pamięci (Kowalewski 2012: 99). Podejmowane przez nich różnorodne działania, zmierzające do zinstytucjonalizowanej resemantyzacji otoczenia (np. stawianie pomników, zmiana nazw ulic, organizacja ekspozycji muzealnych), spotykają się często z krytyką, wchodząc $\mathrm{w}$ konflikt z pamięcią tych środowisk, które z prezentowaną wersją przeszłości nie chcą się utożsamiać. Za sporami o dziedzictwo, jego zakres, strategie ochrony i praktyki użycia kryją się zatem fundamentalne zwłaszcza dla jego mieszkańców 
pytania o tożsamość - o to, kim jesteśmy? kim są nasi przodkowie? gdzie przebiegają granice należącego do nas patrymonium? Odpowiedzi na te pytania nie są jednak ani łatwe, ani jednoznaczne, wielość ról zmusza bowiem do ciągłego balansowania między różnymi polami odniesień.

\section{Dziedzictwo a miejski palimpsest}

W kontekście rozważań o dziedzictwie szczególnie poręczną metaforą wydaje się pojęcie palimpsestu, mówiąc bowiem o semiotycznej złożoności przestrzeni i łącząc ją bardzo wyraźnie z wymiarem temporalnym, zwraca ono jednocześnie uwagę na charakter procesualny, uwikłany w dialektykę zapominania i przypominania. Zaproponowana w latach 90. przez Davida Harveya metafora palimpsestu na określenie miasta jako „wielopłaszczyznowej kompozycji, ukształtowanej z budowli o rożnych formach, jakie mijające czasy nałożyły jedna na drugą" (1996: 27) wydaje się w przypadku semiotycznej lektury centrum Krakowa szczególnie przydatna, bowiem pozwala zrekonstruować zawiłe struktury wyobrażeniowe, związane $\mathrm{z}$ tymi obszarami ${ }^{5}$. Takie spojrzenie na przestrzeń miasta jest $\mathrm{w}$ istocie bardzo podobne do sposobu czytania przestrzeni miejskiej zaproponowanego niegdyś przez semiotyków tartuskich, kładzie jednak mocniejszy akcent na poziom pragmatyki, łącząc interpretację znaczeń z refleksją nad praktykami wykorzystywania przeszłości i zagadnieniami tożsamościowymi. Warto więc przypomnieć uwagi Borisa Uspienskiego na temat istoty opracowywania nowych dziejów miasta, które, jak pisze, polegają

[...] na selekcjonowaniu zdarzeń i nadawaniu im sensu [...] z punktu widzenia teraźniejszości o tyle, o ile pamięć o nich jest nadal żywa w świadomości zbiorowej. Przy tym przeszłość organizuje się jako tekst odczytywany w perspektywie teraźniejszości (Uspieński 1998: 27).

Badanie przestrzeni jako palimpsestu wymaga postawy dystansu i stosowania przy jego lekturze chłodnych, pozbawionych emocji procedur badawczych, poddających się naukowej weryfikacji. Co jednak dzieje się, gdy odkrywaniem jego poszczególnych warstw i rekonstrukcją zajmą się sami użytkownicy tej przestrzeni, powiązani z nią na rozmaite sposoby relacjami politycznymi, ekonomicznymi, religijnymi etc.? Palimpsestowa przestrzeń zaczyna w takiej sytuacji pełnić dla nich funkcję magazynu wypełnionego śladami pamięci, które wyciągnięte na światło dzienne i ułożone w odpowiedniej konfiguracji prezentują wersję przeszłości zgodną z intencjami tychże użytkowników. Wielopoziomowa struktura, będąc „efektem zarówno nawarstwiania i zamazywania, jak i odświeżania, odzyskiwania i odczytywania tego, co dawno zostało pokryte kolejną warstwą znaczenia" (Ko-

5 O historii wprowadzenia do dyskursu naukowego metafory palimpsestu szczegółowo pisze Magdalena Saryusz-Wolska (2011: 179-184). 
walski 2013: 64), umożliwia odnalezienie się w jego ramach różnym wspólnotom pamięci, często konkurującym ze sobą, nierzadko wzajemnie skonfliktowanym ze względu na odmienne doświadczenia historyczne, różne światopoglądy i aktualne interesy polityczne. W ten sposób palimpsest, wchodząc w społeczny obieg, przeistacza się w dziedzictwo, które, jak pisze wspomniany już Krzysztof Kowalski, „zawsze należąc do kogoś, ma ponadto potencjał otwarcia się na inne przynależności i inne interpretacje” (Kowalski 2013: 64).

Traktowanie palimpsestowej przestrzeni miasta jako dziedzictwa niesie ze sobą również istotne konsekwencje praktyczne. Choć jego kreatorzy często nie mówią o tym głośno, ubrana w idealistyczną retorykę gra z przeszłością dzięki swej atrakcyjnej formie może stać się produktem o wymiernej wartości ekonomicznej (Bendix 2009: 259). Dlatego też intensywnie wykorzystuje się jego potencjał w strategiach marketingowych turystyki postmasowej, nastawionej na zaspokojenie potrzeb odbiorcy bardziej wymagającego, który udając się w podróż do jakiegoś miejsca, poszukuje w nim tego, co nietuzinkowe, oryginalne i tajemnicze (Urry 2007; Bendix 2002). Ważne, zwłaszcza w przypadku turystyki kulturowej czy historycznej, by zaliczona do kategorii dziedzictwa atrakcja obdarzona była certyfikatem autentyczności, gwarantowanym przez publiczne autorytety - instytucje władzy, muzea, organizacje społeczno-kulturalne itp.

\section{Czarny Protest}

Wracając do wspomnianego na początku wątku wykorzystywania dziedzictwa jako sceny rytualnej, proponuję skupić się teraz na dwóch konkretnych przypadkach związanych z przestrzenią Krakowa. Na ich przykładzie widać bowiem wyraźnie, jak gęsto zsemityzowana przestrzeń patrymonialna może być różnie odczytywana i reinterpretowana zgodnie z potrzebami jej użytkowników. Przykładami tego dynamicznego procesu zapominania i przypominania, zasłaniania i odkrywania, sakralizacji i sekularyzacji będą tu dwa marsze, jakie przeszły przez Stare Miasto w październiku 2016 roku w związku z rozpoczęciem w polskim sejmie kolejnego etapu prac nad nowelizacją ustawy „o planowaniu rodziny, ochronie płodu ludzkiego i warunkach dopuszczalności przerywania ciąży” z dnia 7 stycznia 1993 roku$^{6}$. Bezpośrednią przyczyną fali protestów, jakie przetoczyły się 3 października przez wiele miast Polski, było złożenie przez komitet „Zatrzymaj aborcję" obywatelskiego projektu ustawy całkowicie zakazującej prawa do usunięcia ciąży ${ }^{7}$. Niecałe trzy tygodnie po Czarnym Proteście komitet „Ratujmy

6 Pełne brzmienie ustawy na stronie Kancelarii Sejmu RP: http://prawo.sejm.gov.pl/isap.nsf/ download.xsp/WDU19930170078/U/D19930078Lj.pdf (dostęp: 5.12.2017).

7 Autorem Apelu do polskich parlamentarzystów o prawo do życia dla każdego poczętego dziecka $i$ ochronę macierzyństwa była Polska Federacja Ruchów Obrony Życia. Postulowano w nim przede wszystkim zmianę obowiązującej od 7 stycznia 1993 roku ustawy „O planowaniu rodziny” po- 
Kobiety" złożył w sejmie swój własny, obywatelski projekt ustawy liberalizującej to prawo.

By zachować chronologię zdarzeń, zacznijmy od marszu, który był ostatnim punktem programu Czarnego Protestu - ogólnopolskiego strajku kobiet zorganizowanego w poniedziałek 3 października 2016 roku. Jego droga wiodła od Rynku Dębnickiego przez most na Wiśle i aleję Słowackiego, ulicami Piłsudskiego, Straszewskiego, Franciszkańską i Grodzką, by ostatecznie dotrzeć na płytę Rynku Głównego pod pomnik Adama Mickiewicza. Po drodze tłum przechodził więc jedną $\mathrm{z}$ dwóch najbardziej reprezentacyjnych tras Starego Miasta, którą przynajmniej od okresu międzywojnia zwyczajowo maszerowały pochody, pielgrzymki, żałobne kondukty i odwiedzające miasto osobistości. Gdy podążałam tego dnia wśród ubranego na czarno tłumu, nieodparcie przychodziły mi na myśl także i moje własne wspomnienia $\mathrm{z}$ tzw. wielkich wydarzeń krakowskich, $\mathrm{w}$ jakich miałam okazję uczestniczyć, znajdując się w tych właśnie miejscach. Choć teraz atmosfera była diametralne inna, mimo woli przed oczami stawały mi zapamiętane sprzed lat obrazy pielgrzymek papieskich. Przejazdy papa mobile odbywały się wszak dokładnie wzdłuż tej samej trasy, biegnącej od alei Trzech Wieszczów przez ulicę Piłsudskiego/Manifestu Lipcowego', Straszewskiego aż po Pałac Biskupi przy Franciszkańskiej. Stojące wówczas po obu stronach drogi tłumy krakowian czekały długo i cierpliwie na to, by choć przez sekundę zobaczyć na własne oczy papieża Polaka i do niego zamachać. Tym razem uczestnicy czarnego marszu przeszli obok papieskiego okna przy Franciszkańskiej 3, nie zatrzymując się przy nim ani chwili. Minęli je w ciszy, którą przerywały jedynie miarowe uderzenia bębnów, wyznaczające rytm pochodu. Na wysokości placu Wszystkich Świętych tłum skręcił w lewo w Drogę Królewską, wypełniając szczelnie ulicę Grodzką. Punktem docelowym był pomnik Adama Mickiewicza stojący po wschodniej stronie Rynku pomiędzy Sukiennicami a kościołem Mariackim.

Zgodnie z przyjętym przez organizatorów planem uczestnicy starali się iść w milczeniu bądź prowadzili przyciszone rozmowy. Na czele marszu szły młode kobiety z zaklejonymi plastrem ustami, które niosły czarny baner z napisem \#BLACKMONDAY. Tuż za nimi kolejna grupa trzymała biały transparent $\mathrm{z}$ hasłem \#CZARNY PROTEST. Jedynymi oficjalnymi dźwiękami, które generował marsz, były odgłosy bębnów podążającej na przodzie kolumny Orkiestry Protestu. Atmosferę napięcia potęgowała obecność ubezpieczającego tłum kordonu

przez całkowite wyeliminowanie z niej tych zapisów, które dopuszczały możliwość aborcji, a więc przypadki, gdy ciąża jest zagrożeniem dla życia lub zdrowia kobiety ciężarnej, przesłanki medyczne wskazują na uszkodzenie płodu, rokujące poważną chorobę i niepełnosprawność dziecka oraz przypadek, gdy „ciąża powstała w wyniku czynu zabronionego”.

8 Konkurencyjny projekt tego komitetu zakładał możliwość przerwania ciąży do 12 tygodnia, edukację seksualną, jawną listę lekarzy powołujących się na klauzulę sumienia i antykoncepcję awaryjną bez recepty.

9 W 1949 roku ulicę Marszałka Józefa Piłsudskiego przemianowano na ulicę Manifestu Lipcowego. Starą nazwę przywrócono w 1990 roku. 
policjantów, ubranych w polowe mundury. Trzymane przez nich w rękach kaski sygnalizowały otoczeniu gotowość do podjęcia czynnej interwencji. Choć wśród maszerujących przeważały kobiety, zwłaszcza w młodszym wieku, nie brak było również mężczyzn, starszych kobiet i matek z dziećmi. Wszyscy uczestnicy byli ubrani na czarno lub w ciemne stroje; część młodych kobiet miała ucharakteryzowane twarze - czarne kreski na twarzy, usta pomalowane czarną szminką lub zalepione plastrami. Protestujący nieśli akcesoria rytualne: transparenty, tablice, kartki A4 z hasłami i ilustracjami w plastikowych koszulkach, wieszaki, czarne balony i wstążki, karykatury z motywami kobiecych narządów płciowych. Większość tych przedmiotów była przygotowana amatorskim sposobem - maszty zrobione z kijów od mioteł i mopów, tablice przylepione taśmami do paczek i lepcami, druciane wieszaki, hasła wykonane odręcznym, nierównym pismem. Generalnie dominowała więc estetyka zwyczajnej codzienności, wzmacniając skutecznie oddolny, spontaniczny i ludyczny wydźwięk protestu.

Kilka minut przed godziną 18 maszerujący tłum dotarł na Rynek pod pomnik Adama Mickiewicza, który od tego momentu wyznaczył symboliczne centrum zgromadzenia. Protestujący zajęli nie tylko przestrzeń wokół pomnika, ale zaanektowali również południowo-wschodnią część Rynku, wchłaniając w ten sposób także najbliższe otoczenie wokół, w tym dziedziniec przed kościołem św. Wojciecha. Kulminacyjny moment protestu, zaplanowany na godz. 18.00, nieoczekiwanie nabrał mocno „krakowskiego charakteru”, bowiem zbiegł się w czasie z rozpoczęciem odgrywania hejnału z wieży mariackiej. Dźwięk trąbki wywołał wśród tłumu wyraźny entuzjazm, rozładowując napiętą atmosferę - protestujący zaczęli spontanicznie machać do hejnalisty i bić mu brawo. Hejnał został potraktowany jako sygnał do rozpoczęcia ostatniej fazy protestu, w trakcie której zgromadzeni skandowali hasła, buczeli i klaskali. Sam kościół Mariacki był w tym czasie prawie pusty i pogrążony w ciszy. Gdy weszłam do niego, by zobaczyć, co dzieje się w jego wnętrzu, u wejścia do nawy głównej zobaczyłam jedynie młodą kobietę w uniformie służb porządkowych bazyliki, która obrzuciła mnie czujnym spojrzeniem. Chwilę później przy jednym $z$ bocznych ołtarzy niewielka grupa wiernych pod przewodnictwem kapłana zaczęła odmawiać różaniec.

Pogrążony zwykle w bezruchu monumentalny pomnik Mickiewicza przeistoczył się błyskawicznie w tętniącą życiem, hałaśliwą trybunę, zmieniając jednocześnie radykalnie swój wygląd. Obok alegorycznych figur Ojczyzny, Poezji, Patriotyzmu i Nauki, przybranych czarnymi wstążkami i wieszakami, stanęli protestujący z transparentami i czarnymi flagami. Co chwilę z pomnika padały hasła, które tłum błyskawicznie podchwytywał, rytmicznie skandując mamy swoje prawa!, myślę, czuję, decyduję!, wolność jest kobietą! i mamy głos!. Równolegle, nieco dalej od pomnika, a tuż obok kościoła św. Wojciecha zapanowała bardziej swobodna atmosfera, przypominająca karnawał. Słychać było pulsujące rytmy samby protestu, wygrywane przez stojących w kole bębniarzy, wokół tańczyli ludzie, jedna z uczestniczek puszczała bańki mydlane. Niektórzy z przechodniów przystawali na 
chwilę przy protestujących, inni przechodzili, nie zwalniając kroku; w okolicznych kawiarniach i restauracjach trwał normalny jak każdego wieczora ruch. Mniej więcej po godzinie od wejścia marszu na Rynek protest dobiegł końca i zatłoczona jeszcze przed chwilą przestrzeń wokół pomnika stopniowo zaczęła się wyludniać. Wkrótce jedynymi materialnymi śladami wydarzenia, które tu się przed chwilą rozgrywało, pozostały wieszaki i wstążki na pomniku Mickiewicza. Uwiecznione na fotografiach i puszczone w medialny obieg, stały się już dzień później jednym z rozpoznawalnych znaków krakowskiej wersji Czarnego Protestu.

$\mathrm{Z}$ antropologicznego punktu widzenia Czarny Protest był właściwie klasycznym rytuałem kontestacji - Max Gluckman zapewne nazwałby go miejskim rytuałem buntu (Gluckman 1963), Victor Turner dramatem społecznym (Turner 1980), Don Handelman wydarzeniem modelującym (Handelman 1998), a Richard Schechner performansem ciała społecznego (Schechner 2006). Ze względu na głęboką strukturę i estetykę tego wydarzenia warto jednak przede wszystkim wrócić do Bachtinowskiej koncepcji karnawału z charakterystycznym dla niego odwróceniem społecznej hierarchii, humorem i groteskowym realizmem (Bachtin 1975: 79). Hiperbolizacja pierwiastka materialno-cielesnego, karnawałowa obsceniczność, która rzuca wyzwanie odgórnie narzuconemu porządkowi normatywno-ideologicznemu, stała się w tym konkretnym kontekście symbolem wolności i oporu wobec planów rządzącej partii narodowo-konserwatywnej, chcącej poprzez kontrolę nad cielesnością Polek zawładnąć ich podmiotowością zgodnie z wyznawanym przez nią światopoglądem katolickim. Stworzony podczas demonstracji pod pomnikiem performans wykreował świat na opak, w którym obowiązujący aktualnie w państwie porządek ideologiczny został zakwestionowany, a oficjalna hierarchia władzy zawieszona. Żałoba mieszała się tu z radością życia, milczenie z wrzawą, formalna słabość ze spontaniczną siłą tłumu. Niezadowolenie i programowa niechęć do władzy przeplatały się z humorem i parodią. Strukturą, czy raczej antystrukturą w Turnerowskim znaczeniu ${ }^{10}$, rządziła ahierarchiczność - głos został oddany tłumowi, który prowadził żywy i spontaniczny dialog $\mathrm{z}$ organizatorami protestu stojącymi na stopniach pomnika. Zawieszenie obowiązujących na co dzień reguł dało się także słyszeć w języku, jakim posługiwali się zgromadzeni, przede wszystkim jednak widać je było na transparentach. Niektóre z nich operowały potocznymi, prowokującymi dosadnością hasłami, odwołującymi się do sfery cielesności i erotyki, przełamując, upubliczniając i wzmacniając tabuizowaną na co dzień seksualność ${ }^{11}$. Bunt wobec władzy stał się

${ }^{10}$ Antystrukturę, która pojawia się u Turnera w kontekście rozważań o communitas, cechuje egalitaryzm, bezpośredniość, niezróżnicowanie, nieracjonalność, relacja Ja - Ty, wynikające z czasowego zawieszenia ustrukturyzowanego porządku formalnych więzi społecznych (Turner 2005: 34-35).

11 A oto kilka przykładów haseł, jakie pojawiły się na transparentach: Moje ciało, moja decyzja!, Prawa kobiet prawami człowieka!, Rząd nie ciąża, usunać go można!, 'Tak' dla wyboru, 'nie' dla terroru!, O prawo wyboru walczyć będziemy do oporu!, Nasze mamy miały wybór!, Nam to nie zwisa!, 
jednocześnie okazją do sprzeciwu wobec konserwatywno-nacjonalistycznej biopolityki, zamanifestowania własnej wizji obywatelskości i prawa do publicznego głosu.

W wypisanych po polsku i angielsku napisach na transparentach postulaty feministyczne przeplatały się z antyklerykalnymi i liberalnymi. W demokratycznej polifonii haseł pojawiły się jednak również i takie, które odwoływały się do kodu narodowego - Quo Vadis Polsko? Polska jest kobieta! czy Matko Polska! Wyeksponowane $\mathrm{w}$ pobliżu pomnika, weszły $\mathrm{w}$ semantyczną interakcję $\mathrm{z}$ jego programem ikonograficznym, dodając do niego aktualne treści. Siedząca u stóp wieszcza kobieca postać z uniesioną ręką, odziana w powłóczystą szatę i zastygła w monumentalnej pozie - figura, której Teodor Rygier wyznaczył niegdyś rolę Ojczy$z^{12}{ }^{12}$, wydawała się nabierać teraz nowego życia. Oto romantyczna Matka Polka - opiekunka i strażniczka narodu, wcielenie kultu instynktu i serca (Janion 1986: 153), ujawniła swą drugą twarz - nieustraszonej Wojowniczki ${ }^{13}$, gotowej stoczyć kolejną bitwę za wolność, tym razem jednak już na własnych, kobiecych zasadach. Wykorzystanie pomnika Mickiewicza jako centrum przestrzeni protestu nieoczekiwanie przywołało romantyczne figury buntu i wolności i włączyło je w rytualną akcję. Przetłumaczone na język współczesności, zostały inkorporowane w nową rzeczywistość, wykraczającą daleko poza lokalny kontekst polityczno-społeczny. Dzięki setkom smartfonów zaistniały również w globalnej, wymykającej się politycznej cenzurze cyberprzestrzeni, o której istnieniu przypominał zresztą obecny na transparentach przez cały czas trwania wydarzenia hasztag.

\section{Biały Marsz}

Drugi przypadek, o którym chciałam wspomnieć, to zorganizowany tydzień później tzw. Biały Marsz, czyli Marsz Dla Życia i Rodziny, będący w zamyśle organizatorów odpowiedzią na wspomniany przed chwilą Czarny Protest. Zorganizowany pod hasłem obrony rodziny i tradycyjnych wartości chrześcijańskich, a zwłaszcza obrony życia poczętego, w przeciwieństwie do ponurej scenerii poniedziałkowego wieczoru odbywał się $\mathrm{w}$ słoneczne, niedzielne popołudnie 9 października. Marsz wyruszał z dwóch różnych miejsc - kościoła św. Józefa w Rynku Podgórskim i Sanktuarium św. Jana Pawła II w Łagiewnikach, a kończył się przy kościele św. Wojciecha na Rynku Głównym. Te trzy miejsca w szczególny

Średniowiecze już było!, Sio od cipek!, Przestańcie nam grzebać w majtkach!, No woman no kraj!, I can't believe I'm protesting for this shit in 2016.

12 Pomnik, zaprojektowany przez Teodora Rygiera, został ostatecznie odsłonięty w 1898 roku.

13 Jak pisze Alicja Kusiak, w okresie romantyzmu obowiązywały równolegle dwa wzory kobiecego patriotyzmu. Jednym z nich była Polka jako strażniczka ogniska domowego i Matka Narodu, drugim zaś Wojowniczka-Patriotka. Obie te figury miały charakter alegoryczny i melodramatyczny, cierpiąc w konsekwencji na „chroniczną esencjalizację” (Kusiak 2006: 241). 
sposób związane z kultem św. Jana Pawła II, najważniejszego patrona katolickich ruchów pro-life, zakreśliły przestrzenne i zarazem semantyczne ramy dla całego wydarzenia ${ }^{14}$.

Wśród maszerujących przeważały osoby starsze, choć nie brak było również ludzi młodych i rodzin z dziećmi; pojawiło się także sporo osób duchownych młodych księży, kleryków i zakonnic. Ze względu na porządek, w jakim ustawiono uczestników, marsz był swoistym połączeniem pochodu z procesją religijną. $\mathrm{Na}$ jego czele kilkuosobowa grupa niosła baner z napisem Pierwszy Małopolski Marsz Dla Życia i Rodziny, na którym umieszczono również znaki patronów honorowych tego wydarzenia - herb ówczesnego Metropolity Krakowskiego kardynała Stanisława Dziwisza oraz logo Wojewody Małopolskiego, a także nazwy instytucji współorganizujących całe przedsięwzięcie ${ }^{15}$. Za nią szły poczty sztandarowe organizatorów marszu, bractw religijnych i pozostałych, niewymienionych na transparencie organizacji społeczno-politycznych o narodowo-katolickiej orientacji. Czoło pochodu zamykała orkiestra górnicza. Szczególne zagęszczenie semantyczne pojawiło się tam, gdzie niesiono relikwie Jana Pawła II wraz z jego portretem - towarzyszyły im bowiem flagi narodowe, papieskie i maryjne, a także portret Matki Teresy z Kalkuty. W ich cieniu grupa starszych kobiet modliła się na ogromnym drewnianym różańcu. Oficjalną część pochodu zamykała kolumna idąca $\mathrm{z}$ długim na kilkadziesiąt metrów szerokim pasem białej tkaniny, zapisanej odręcznie fragmentami papieskiej adhortacji Redemptoris Custos $^{16}$. Maszerujący w pochodzie ludzie zachowywali się swobodnie, niektórzy machali białymi i żółtymi balonami z napisami ŻYCIU - TAK. W pogodnym tłumie pojawiło się jednak także kilka osób, które z ostentacyjną powagą niosły własne hasła i fotografie, na których antyaborcyjne hasła łączyły się płynnie $\mathrm{z}$ nacjonalistyczną retoryką ${ }^{17}$. Fonosferę pochodu nieustannie wypełniały głośne

14 W kościele św. Wojciecha odprawiana jest każdego dnia wieczorem msza św., która rozpoczyna się o 21.37, a więc dokładnie w godzinę śmierci Jana Pawła II. Z kolei w Rynku Podgórskim przy kościele św. Józefa funkcjonuje Kamieniołom im. Jana Pawła II - obecnie centrum edukacyjno-artystyczne i religijne, a w okresie PRL także ważny ośrodek niezależnej myśli politycznej i baza Solidarności. Natomiast Centrum im. Jana Pawła II w Łagiewnikach to obecnie centralny ośrodek kultu św. Jana Pawła II w Polsce. Szerzej o krakowskich miejscach kultu Jana Pawła II pisze Anna Niedźwiedź (2014: 79-102).

15 Szczególowy spis instytucji sprawujących oficjalny patronat nad Marszem - zob. przypis 19.

16 Wydana w 1989 roku adhortacja ta jest oficjalnym wykładem papieża na temat roli św. Józefa w dziejach Kościoła. Apologetyczny obraz opiekuna Jezusa, męża Maryi pokazuje, jak istotną funkcję miał on pełnić w historii Zbawienia. Autor tekstu stawia go katolikom także za wzór mężczyzny jako ojca i opiekuna rodziny. Wypisaną na zwoju materiału adhortację przywieźli ze sobą do Krakowa członkowie szczecińskiego Bractwa Małych Stópek - katolickiej fundacji pro-life. Instytucja ta zorganizowała w 2016 roku wśród uczniów akcję przepisywania na pasach tkaniny tekstu Redemptoris Custos, które zszyte później w jedną całość służyły uczestnikom „marszów dla życia”. Zob. http:// dlazycia.info/historia/ (dostęp: 8.12.2017).

17 A oto przykład jednego z tego typu napisów: Aborcja - maszyna śmierci w celu wymordowania Narodu, aby liczebność zmalała do 18 milionów. Naród mały nie liczy się w świecie. 
dźwięki religijnych pieśni i modlitw, przeplatane komunikatami organizatorów informujących o idei marszu; $w$ antraktach rozbrzmiewała orkiestra górnicza.

Gdy pochód dotarł do wylotu ulicy Grodzkiej, zatrzymał się na chwilę przy Krzyżu Katyńskim, by wspomnieć ofiary reżimu komunistycznego i katastrofy lotniczej pod Smoleńskiem z 2010 roku. Około godziny 13 marsz wkroczył na Rynek Główny. Kolumna z białą wstęgą otoczyła pomnik Mickiewicza i na moment zupełnie zagarnęła przestrzeń, tworząc wokół niego wielki biały krąg; następnie ustawiła się równolegle do Sukiennic, wyznaczając w ten sposób granicę przestrzeni, na której odbywała się dalsza część zgromadzenia. Jego centrum stanowiła teraz scena, gdzie ustawiono portrety św. Jana Pawła II i św. Matki Teresy oraz relikwiarz z figurą Matki Boskiej Brzemiennej ${ }^{18}$. Kościół św. Wojciecha stworzył dla sceny nie tylko tło, ale również symboliczną ramę, zakotwiczając rozgrywające się przed nim wydarzenia w perspektywie blisko tysiącletniej obecności Kościoła na tym miejscu. Dalsza część wydarzenia stała się właściwie spektaklem władzy, na scenie przemawiali bowiem w hierarchicznym porządku kardynał Stanisław Dziwisz oraz szefowie instytucji współorganizujących marsz ${ }^{19}$. W trakcie przemówień słychać było hejnał $\mathrm{z}$ wieży mariackiej, jednak zgromadzony tłum nie zwrócił na niego uwagi, skoncentrowany na tym, co działo się właśnie na scenie. Wydaje się, że jedynym niezaplanowanym przez reżyserów całego przedsięwzięcia epizodem było powtórne wystąpienie kardynała Dziwisza, który tuż przed zejściem ze sceny raz jeszcze podszedł do mikrofonu i bez żadnych wstępów zapewnił, że „nie ma mowy o karaniu kobiet za aborcję". Na koniec wyznaczeni lektorzy czytali świadectwa rodziców niepełnosprawnych dzieci, a dziecięcy zespół wokalny dał krótki koncert. Podobnie jak podczas poniedziałkowego Czarnego Protestu niektórzy z przypadkowych przechodniów przystawali na chwilę, przyglądając się zgromadzonym; w pozostałych rejonach Rynku panowała typowa dla niedzielnego popołudnia niespieszna, swobodna atmosfera.

$\mathrm{Z}$ punktu widzenia struktury wydarzenia i generowanych przez nie treści można je zaliczyć zarówno do rytuałów władzy, jak i ceremonii religijnych. Przemawiający do zebranych aktorzy tego spektaklu posługiwali się hybrydalnym stylem językowym, będącym kompilacją języka przemówień politycznych i kazań; formuły modlitewne i pieśni religijne przeplatały się z krytyką środowisk liberalno--lewicowych oraz rygorystycznymi postulatami polityki prokreacyjnej i prenatalnej. Panował uroczysty, ale też i pogodny nastrój; uczestnicy byli nastawieni do siebie przyjaźnie, zachowywali się spokojnie i reagowali zgodnie z in-

18 Autorem wykonanej w srebrze figury Matki Boskiej Brzemiennej jest Mariusz Drapikowski, natomiast zleceniodawcą relikwiarza działające w Krakowie Polskie Stowarzyszenie Obrońców Życia Człowieka.

19 Na scenie zabrali głos: prezes Zarządu DIAK Grażyna Kominek, kard. Stanisław Dziwisz, posłanka listy PiS i wieloletnia prezes KIAK Halina Szydełko, prezes Polskiej Federacji Ruchów Obrony Życia Paweł Wosicki oraz prezes Polskiego Stowarzyszenia Obrońców Życia w Krakowie Antoni Zięba. 
tencjami organizatorów. Mimo oficjalnych haseł nawołujących do zmiany prawa, tak scenariusz, jak i rzeczywisty przebieg całego wydarzenia doskonale wpisywały się $\mathrm{w}$ realizowany przez obecną władzę projekt polityki społecznej, zakotwiczony w ideologii narodowo-konserwatywnej. Ze względu na swoją performatywną naturę marsz intensywnie angażował swych uczestników, generując za pomocą różnorodnych bodźców oddziałujących na ich zmysły pożądane przez organizatorów uczucia i wyobrażenia. $Z$ tego punktu widzenia niezwykle interesujący wydaje się moment, gdy niosący adhortację wkroczyli na Rynek i okrążyli pomnik. W kontekście wydarzeń, które rozegrały się tu kilka dni wcześniej, nieodparcie rodzi się skojarzenie z rytualnym gestem symbolicznego oczyszczania i zabezpieczenia zagrożonej przestrzeni poprzez procesyjne okrążanie granic, jaki znamy chociażby z dziejów wielkich katastrof średniowiecznej Europy czy polskiej obrzędowości wiosennej (Gębarowicz 1986: 15; Klimaszewska 1981: 143). Podążając tym tropem interpretacyjnym, otoczony białą wstęgą pomnik Mickiewicza, „skalany” kilka dni wcześniej przez wieszaki i gorszące hasła, został przez maszerujących na powrót „oczyszczony” jako narodowe patrymonium. Odwołując się do refleksji Birgit Mayer i Marleen De Witte na temat dynamiki relacji między dziedzictwem a religią, działanie uczestników Białego Marszu można więc w tym przypadku uznać za klasyczny przykład procesu sakralizacji dziedzictwa (2013: 277).

\section{Podsumowanie}

Porównując oba wydarzenia, bez trudu daje się zauważyć, że ich uczestnicy w ostatniej, kulminacyjnej fazie operowali w tej samej przestrzeni, czyli po wschodniej stronie Rynku Głównego, który przez większość krakowian uważany jest za centralny punkt Starego Miasta i funkcjonuje jako tradycyjne miejsce najważniejszych rytuałów miejskich (Pilichowska 1993). Jako scena rytualna o wyjątkowym znaczeniu w przestrzeni symbolicznej Krakowa nadała zatem odpowiednio wysoką rangę organizowanym tu imprezom. Podobieństwo widać także w ogólnej formule tych wydarzeń, która opierała się na schemacie politycznego marszu. Oba koncentrowały się również wokół tego samego problemu, czyli de facto kształtu systemu normatywno-prawnego biopolityki uprawianej przez państwo. Choć Biały Marsz w fazie początkowej był przede wszystkim rytuałem religijnym, finalnie stał się rytuałem politycznym - wiecem poparcia dla projektu nowej ustawy, którą Czarny Protest ostentacyjnie kilka dni wcześniej zakwestionował.

Zasadnicze różnice dotyczą natomiast głębokiej struktury tych wydarzeń. Protest stworzył z premedytacją sytuację rytualnego chaosu. Podkreślał egalitarność, oddolność i spontaniczność działań jego uczestników, zjednoczonych wokół wspólnej sprawy. Dlatego też nie było tu publicznie słychać nazwisk, tytułów i nazw organizacji. W Białym Marszu wyraźnie rzucały się w oczy uporządkowanie i hierarchiczność, dyscyplina i oficjalność, oparte na wyreżyserowanej insce- 
nizacji. Estetyka Czarnego Protestu operowała karnawałowo-żałobną konwencją, w której dominowała prowokacyjna potoczność, groteska i dosadność, łamiąca obowiązujące na co dzień konwencje kulturowe. Z kolei w Białym Marszu przeważała konwencjonalna odświętność, hiperpoprawność, estetyka ołtarza i pochodu. Znaczące różnice generowały również pora dnia i warunki atmosferyczne, w jakich odbywały się oba wydarzenia. Pierwsze z nich rozegrało się, jak pamiętamy, w poniedziałkowe późne popołudnie, a zakończyło się już w ciemnościach wieczoru. Dramaturgii dodawał także deszcz i przenikliwy chłód, intensyfikując fizyczne doświadczenie przemocy i frustrację protestujących. Z kolei Marsz dla Życia odbywał się w Dzień Papieski, w samym środku niedzielnego, słonecznego i ciepłego jak na październik dnia. Pogodna aura sprzyjała budowaniu nastroju radości i optymizmu, znakomicie korespondując z hasłami o ochronie życia poczętego i rodzinnym szczęściu. Mimo że uczestnikami czarnego marszu byli również mężczyźni, głos należał przede wszystkim do kobiet, wśród których przeważały osoby w młodszym wieku. Maszerujący $\mathrm{z}$ adhortacją byli ludźmi w różnym wieku z wyraźną jednak przewagą osób starszych oraz widocznym udziałem duchowieństwa; choć w głośnikach rozbrzmiewały różne głosy, najważniejsze słowa $\mathrm{z}$ ołtarza i sceny padały z ust mężczyzn.

I w końcu to, co z punktu widzenia naszych rozważań na temat dziedzictwa wydaje się najistotniejsze. Uczynienie z niewielkiego kościoła św. Wojciecha, znanego jako jedna z najstarszych zachowanych świątyń w Krakowie, centrum Białego Marszu mało przypomnieć o obecności w samym środku Rynku miejsca, które od wieków stoi na straży porządku moralnego i życia duchowego „Miasta Królów Polskich"20. Wyeksponowało sakralny wymiar tego zabytkowego obiektu, funkcjonującego na co dzień przede wszystkim jako atrakcja turystyczna Krakowa. Z kolei podczas Czarnego Protestu centrum rytuału wyznaczył pomnik Mickiewicza, wykorzystany jako trybuna politycznej kontestacji. Oswoił, przetłumaczył nowe, feministyczne, lewicujące i liberalne hasła na powszechnie znane Polakom podstawowe figury dyskursu patriotycznego, ukształtowane jeszcze w epoce romantyzmu. Wolność i niezależność, które do tej pory sublimowały sprzeciw wobec politycznych wrogów Polski - zaborców, okupantów, komunistycznej władzy zostały włączone w nowy kontekst polityczny walki o prawa równościowe, wolność wyboru i świecki charakter państwa, zaś zewnętrznym wyrazem tej nominacji pomnika było przystrojenie go wieszakami i czarnymi wstążkami. Choć niespełna tydzień później pomnik wieszcza został odzyskany przez maszerujących

20 Od 2014 roku przy kościele św. Wojciecha została założona wspólnota modlitewna Szpital Domowy. O jej programie ideowym i celach możemy przeczytać na stronie internetowej Kościót Świętego Wojciecha: „My młodzi chrześcijanie, pamiętając o wielkiej historii Krakowa, nie chcemy, aby w naszym mieście propagowana była nieczystość i by nakłaniano nas do grzechu. Pochodzimy z różnych wspólnot czy duszpasterstw i chcemy się razem modlić o moralną odnowę Miasta Królów Polskich. Od dwóch lat spotykamy się codziennie przed Panem Jezusem w Najświętszym Sakramencie i prosimy Go, aby uzdrowił nasze Miasto i przebywających w nim ludzi - mieszkańców i przejezdnych" (http://wojciechnarynku.pl/szpital-domowy/idea/ [dostęp: 14.12.2017]). 
Białych i symbolicznie oczyszczony jako narodowe dziedzictwo, wiosną 2017 roku w dzień Międzynarodowego Strajku Kobiet przeistoczył się ponownie w trybunę protestu.

\section{Bibliografia}

Bachtin M.,

1975 Twórczość Franciszka Rabelais'go a kultura ludowa Średniowiecza i Renesansu, przeł. A. Goreń, A. Goreń, Kraków.

Bendix R.,

2002 Capitalizing on Memories Past, Present, and Future. Observations on the Intertwining of Tourism and Narration, „Anthropological Theory”, vol. 2, issue 2, s. 469-487.

2009 Heritage between Economy and Politics. An Assessment from the Perspective of Cultural Anthropology, [w:] Intangible Heritage, eds. L. Smith, N. Akagawa, London-New York, s. 253-269.

De Witte M., Mayer B.,

2013 Heritage and the Sacred: Introduction, „Material Religion”, vol. 9, issue 3, s. 274$-281$.

Gębarowicz M.,

1986 Mater Misericordiae, Pokrow, Pokrowa w sztuce i legendzie środkowo-wschodniej Europy, Wrocław.

Gluckman M.,

1963 Order and Rebellion in Tribal Africa, London.

Handelman D.,

1998 Models and Mirrors. Towards an Anthropology of Public Events, New York. Harrison R.,

2015 Heritage and Globalization, [w:] The Palgrave Handbook of Contemporary Heritage Research, eds. E. Waterton, S. Watson, New York, s. 297-311.

Harvey D.,

1996 Kwestia urbanizacji, przeł. A. Majer, „Kultura i Społeczeństwo”, nr 4, s. 15-42.

Janion M.,

1986 Zbroja Grażyny, [w:] Maski, t. I, red. M. Janion, S. Rosiek, Gdańsk, s. 148-159.

Klimaszewska J.,

1981 Doroczne obrzędy ludowe, [w:] Etnografia Polski. Przemiany kultury ludowej, t. II, red. M. Biernacka, M. Frankowska, W. Paprocka, Wrocław, s. 127-153.

Kowalewski J.,

2012 Kreacje przeszłości. Szkice z antropologii historii, Olsztyn.

Kowalski K.,

2013 O istocie dziedzictwa europejskiego - rozważania, Kraków.

Kusiak A.,

2006 Narodowa pamięć historyczna a historia kobiet, [w:] Polska: medium, cień, wyobrażenie, red. M. Gabryś, M. Rudaś-Grodzka, B. Smoleń, Warszawa, s. 214-217.

Lowenthal D.,

1998 La fabrication d'un heritage, [w:] Patrimoine et modernité, éd. D. Poulot, Paris, s. $111-126$. 
Neal C.,

2015 Heritage and Participation, [w:] The Palgrave Handbook of Contemporary Heritage Research, eds. E. Waterton, S. Watson, New York, s. 346-364.

Niedźwiedź A.,

2014 Competing Sacred Places: Making and Remaking of National Shrines in Contemporary Poland, [w:] Pilgrimage, Politics and Place-Making in Eastern Europe: Crossing the Borders, eds. J. Eade, M. Katić, Farnham, Berlington, s. 79-102.

Pilichowska B.,

1993 Rok obrzędowy na krakowskim rynku w minionych stuleciach, [w:] Kraków: przestrzenie kulturowe, red. J. Bujak, A. Zambrzycka-Kunachowicz, R. Godula, Kraków, s. $27-50$.

Rothenbuhler D.,

2003 Komunikacja rytualna, przeł. J. Barański, Kraków.

Saryusz-Wolska M.,

2011 Spotkania czasu z miejscem. Studia o pamięci i miastach, Warszawa.

Schechner R.,

2006 Performance Studies: A Critical Introduction, London.

Schramm C.,

2015 Heritage, Power and Ideology, [w:] The Palgrave Handbook of Contemporary Heritage Research, eds. E. Waterton, S. Watson, New York, s. 442-456.

Turner V.,

1980 Social Dramas and Stories about Them, „Critical Inquiry”, vol. 7, no. 1, s. 141-168. 2005 Gry społeczne, pola i metafory. Symboliczne działanie w społeczeństwie, przeł. W. Usakiewicz, Kraków.

Urry J.,

2007 Spojrzenie turysty, przeł. A. Szulżycka, Warszawa.

Uspieński B.,

1998 Historia i semiotyka, przeł. B. Żyłko, Gdańsk.

\section{Materiały internetowe}

Bractwo Małych Stópek:

http://dlazycia.info/historia/ (dostęp: 8.12.2017).

Kancelaria Sejmu RP:

http://prawo.sejm.gov.pl/isap.nsf/download.xsp/WDU19930170078/U/D19930078Lj. pdf (dostęp: 5.12.2017).

Kościół Świętego Wojciecha:

http://wojciechnarynku.pl/szpital-domowy/idea/ (dostęp: 20.12.2017).

Narodowy Instytut Dziedzictwa:

https://www.nid.pl/pl/Informacje_ogolne/Ochrona_dziedzictwa_kulturowego/

(dostęp: 10.11.2017).

Projekt badawczy HERILIGION:

http://www.etnologia.uj.edu.pl/kadra/badania/heriligion.poland (dostęp: 10.12.2017). 